\title{
The Role of Zakat, Infaq and Shadaqah (ZIS) in Reducing Poverty in Aceh Province
}

\author{
Eko Gondo Saputro \\ Universitas Islam Indonesia, Indonesia \\ Corresponding email: ekogondosaputro@gmail.com \\ Sahabudin Sidiq \\ Universitas Islam Indonesia, Indonesia, sahabudinsidia@gmail.com
}

Received: June $5^{\text {th }}, 2020$

Article History

Revised: August $6^{\text {th }}, 2020$ Accepted: August $30^{\text {th }}, 2020$

\begin{abstract}
Aceh is one of the provinces that paves the way for the Islamic development in Indonesia. Therefore, Aceh has a strong Islam preaching and becomes the center of science. Innovations made in Islamic knowledge with government policies in managing zakat funds collected from the community-made Aceh are through the BAZNAS in provincial level namely Baitul Mal Aceh; one of the BAZNAS with highly effective Allocation to Collection Ratio (ACR) levels. Baitul Mal Aceh has a superior program aiming at making Mustahik into Muzzaki consisting of education, health assistance, and economic empowerment programs. This research was conducted to see the effect of Zakat, Infaq, Shadaqah (ZIS) through Economic Growth, Education, Health, and HDI on Poverty in Aceh. The method used in this research was Structural Equation Model-Partial Least Square (SEM-PLS). The results revealed the direct effect of ZIS on Economic Growth, Health, and HDI, as well as the total indirect effect of ZIS on Economic Growth and Poverty in Aceh. The results also showed that the effect of ZIS through Health and HDI on Economic Growth and the effect of ZIS through HDI on Poverty in Aceh.
\end{abstract}

Keywords: ZIS, Poverty, PLS

JEL Classification: P36, D31, I3

@ IJIEF 2020 published by Universitas Muhammadiyah Yogyakarta, Indonesia All rights reserved

DOI:

https://doi.org/10.18196/ijief.3234

Web:

https://journal.umy.ac.id/index.php/ijief/article/view/8965

Citation:

Saputro, E. G., \& Sidiq, S. (2020). The role of zakat, infaq and shadaqah (ZIS) in reducing poverty in Aceh Province. International Journal of Islamic Economics and Finance (IIIEF), 3(2), 63-94. DOI: https://doi.org/10.18196/ijief.3234 


\section{Introduction}

\subsection{Background}

According to Muhammad (2004) historians estimate that Islam entered Aceh through Perlak or Samudera Pasai in the $7^{\text {th }}$ or $9^{\text {th }}$ century $A D$ and immediately came from Makkah to Aceh until then the Province of Aceh was announced as the city of "Serambi Makkah". Because of the rapid development on Islamic teachings, Aceh has become the center for Islamic science to date. These Islamic values not only put in science, but also modified with the programs of Aceh provincial government that have welfare effects on the community itself. One of them is how the Aceh government, through the National Zakat Board (BAZNAS) of Aceh, utilizes the collected zakat funds to be distributed to fields that are considered to improve the community welfare such as in the fields of education, health, and economy.

According to the Indonesia Zakat Outlook Report in 2018, it was explained that Aceh through Aceh-provincial-based BAZNAS (Baitul Mal Aceh) was categorized as one of the provinces with a highly effective ACR (Allocation to Collection Ratio) percentage. This shows how the implementation of Islamic Sharia law in Aceh community is tremendously firm and community support for amil zakat bodies in collecting zakat funds. Then, the zakat funds collected shall later be distributed to benefit the community welfare in general, which absolutely, shall be perceived by the community of Aceh in particular.

In the implementation of zakat distribution programs aimed at the welfare of Aceh community, several problems are frequently encountered which are usually common to afflict even in other areas, namely poverty. The problem of the high poverty rate is still a major problem in the Indonesian economy. The percentage of poverty in Aceh, which is quite higher than other provinces in Indonesia, becomes a big problem for Aceh. 


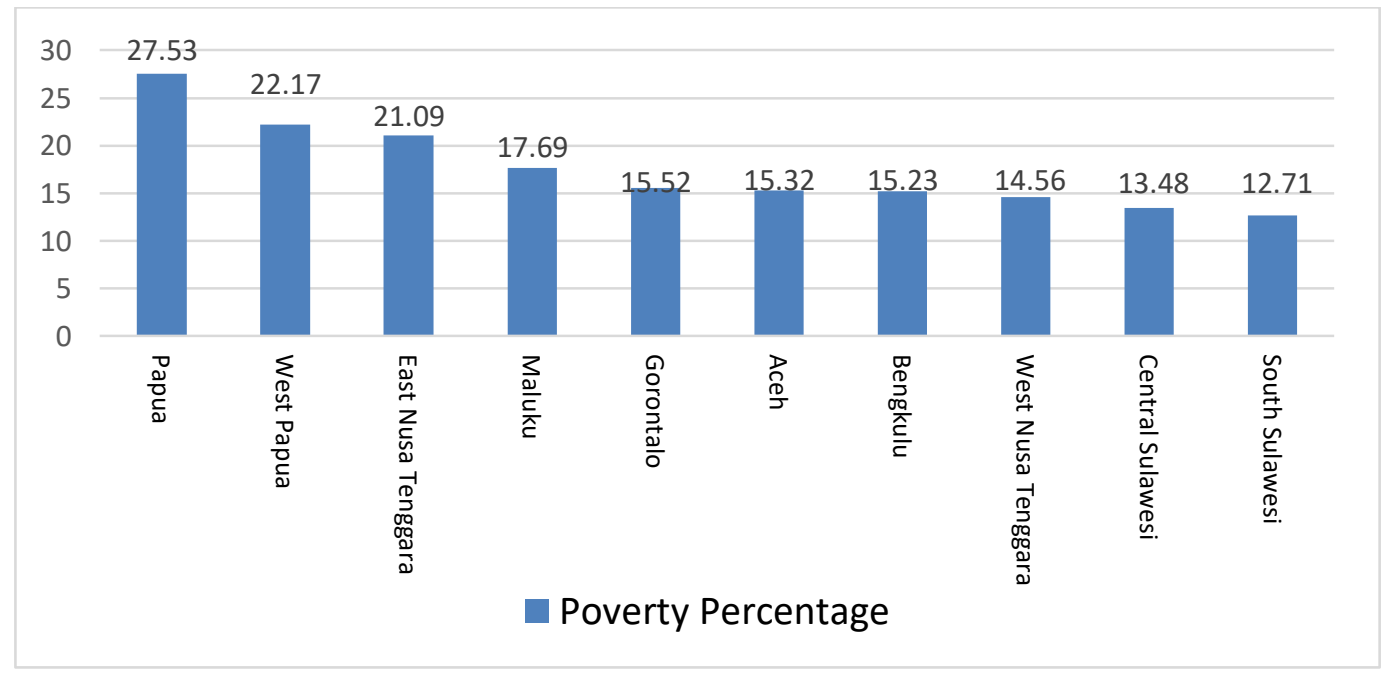

Figure 1. Poverty Percentage, 2019

Source: Central Bureau of Statistics of the Republic of Indonesia (BPS)

The data on figure 1 shows the 10 provinces in Indonesia which have the largest percentage of poverty in 2019. It can be seen that Aceh is ranked $6^{\text {th }}$ with the highest percentage of poverty out of 34 Provinces in Indonesia with a percentage of poverty of $15.32 \%$. This shows that one of the regions contributes the highest percentage of poverty in Indonesia is Aceh. It can be concluded that one of the major problems faced by the Aceh Provincial Government in achieving the ultimate goal of distributing zakat funds for community welfare is poverty.

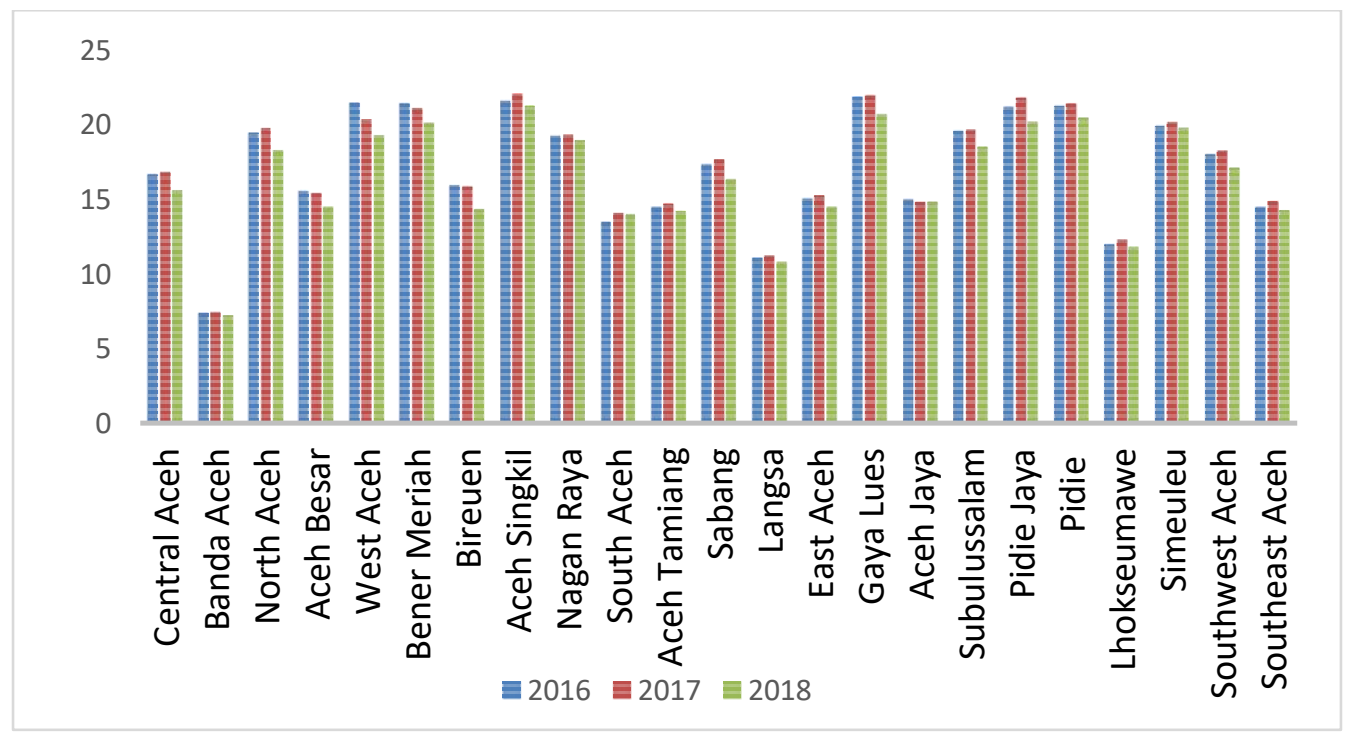

Figure 2. Percentage of Poor Population of Regencies/Cities in Aceh (2016-2018) Source: Central Bureau of Statistics of the Republic of Indonesia (BPS) 
Saputro \& Sidiq | The Role Of Zakat, Infaq and Shadaqah (ZIS) in Reducing Poverty in Aceh Province

Figure 2 shows the percentage of poor population in Aceh regencies/cities during the 2016-2018 period. The regencies with the highest percentage of poor population are Aceh Barat, Bener Meriah, Aceh Singkil, Gayo Lues, Pidie Jaya, and Pidie, with poverty percentages in the six regencies showing an average of $17,21 \%$. The regency with the lowest percentage of poor population is Banda Aceh with a poverty rate of $7 \%$. It is because Banda Aceh regency is the economic center of Aceh. However, when viewed from fluctuations that occur from 23 regencies/cities in Aceh, most experience fluctuations but tend to decline, except for 2 regencies namely Aceh Besar and Aceh Jaya which experience fluctuations but tend to increase. Even though most of the regencies/cities experience fluctuations that tend to decline, the percentage of poverty is still fairly high because it ranges from $11 \%$ to $20 \%$. It tends to decrease during the period from 2016 to 2018, but most of the regencies/cities in Aceh have high percentage of the poor population.

Islam has a serious concern in reducing poverty. Islam commands its people not to feel that their possessions are their full property, yet in that property, there is a right for others. The form of obligation in issuing a portion of assets for each Muslim is interpreted in the third pillar of Islam, namely zakat. According to Mulajawan et al., (2016), zakat is an obligation commanded by Allah SWT to issue certain assets to certain parties. This explains that the assets we have are entirely not ours, but also "rights" for certain parties. Thus, it can be stated that zakat is one of the forms of instrument in Islam which becomes one of the tools in reducing poverty. Then, it becomes an obligation that must be fulfilled by each individual in a certain period.

The most considered attention of Aceh provincial government to the obligations of its people in carrying out the commands of Allah SWT is zakat. The combination of local regulations issued by the Aceh provincial government with Islamic Sharia law (Qanun) aiming to benefit the economic potential of Moslems can run effectively and the community can feel the benefits, especially in the local economy. 


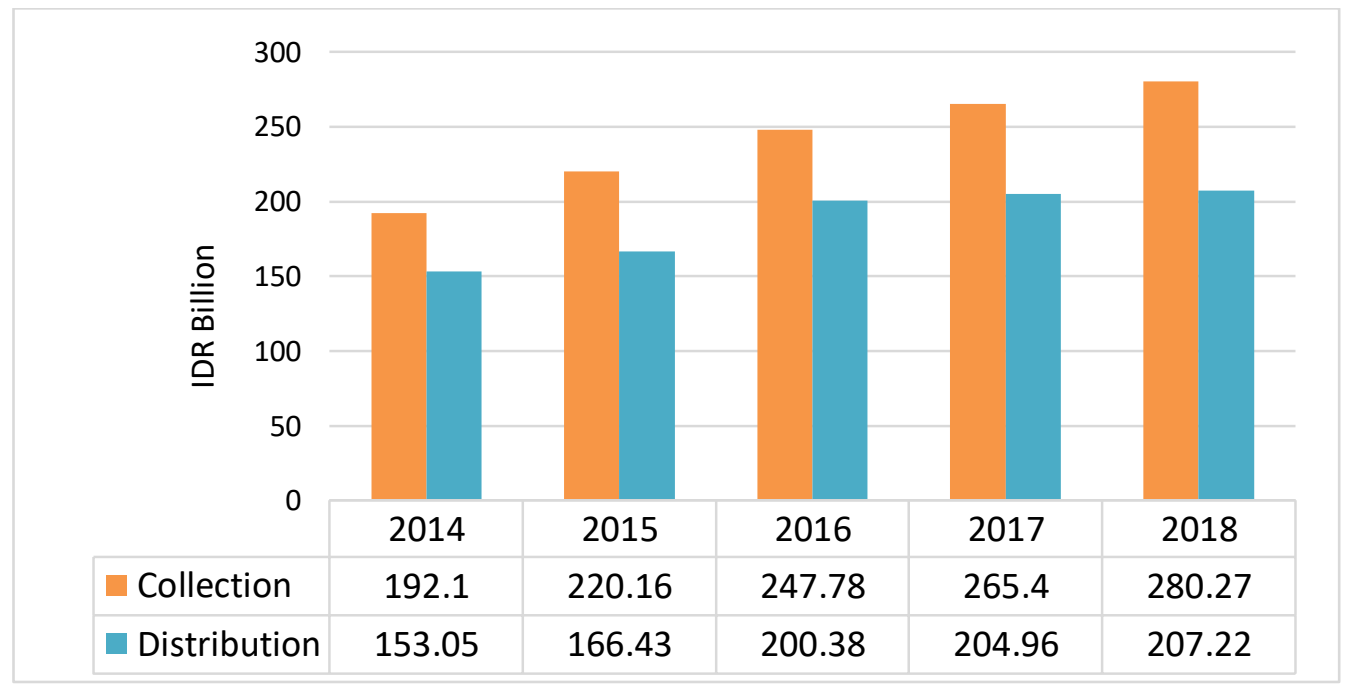

Figure 3. Total Collection and Distribution of ZIS in Aceh (2014-2018)

Source: Baitul Mal Aceh

Based on the data above, it can be seen that the collection and distribution of zakat in Aceh regency/city in stretches every year always increase. The distribution form of zakat in education field is in form of providing education assistance or scholarship for the poor starting from the elementary school level to the Diploma level. Furthermore, in the health field, the poor shall get good health facilities and infrastructure. The last is community economic empowerment program that aims to make mustahik to be muzzaki, which means making those who are in poverty to be economically independent in order that they can issue zakat.

Most of the previous researchers analyzed zakat on poverty to see how the direct effect of zakat on poverty reduction in a region. It can be known from the research conducted by Akram \& Afzal (2014) which explained the longterm and short-term effects of zakat on poverty in Pakistan, or Athoillah (2018) which explained that zakat has effects in increasing economic growth and reducing poverty in Java. However, the distribution of zakat funds is done through several components so that it can be stated that it can reduce poverty or poverty reduction is not necessarily because of the effect of zakat. Therefore, the present research will examine further on how zakat through components or other variables is related to variables that play a role in poverty reduction such as education, health, and Human Development Index (HDI). 


\subsection{Objectives}

Based on the research background aforementioned, this present study will examine how the effect of Zakat, Infaq, Shadaqah (ZIS) through Education, Health, and HDI in reducing poverty in Aceh. It is then proceeded to ensure that the analysis results are in line with the achievement of the ZIS distribution program carried out by Baitul Mal Aceh in its efforts to reduce poverty in Aceh. It is expected that this research will have a good effect not only in Aceh particularly, but also in Indonesia in terms of zakat management so that it can maximize the existing potential to overcome the poverty.

The paper comprises five sections. The first is Introduction, followed by the literature review, methodology in the third section; the result and analysis in fourth section; and the final section presents the conclusion and recommendations.

\section{Literature Review}

\subsection{Zakat in Macroeconomics}

According to the macroeconomic aspect, zakat has various important economic implications, among others, allocative efficiency, macroeconomic stability, social security, income distribution, and economic growth. Zakat transfers part of the rich income that is generally the small part of society to the poor who is generally the largest part of society. Therefore, this will directly increase the demand for goods and services from the poor, which are basic needs in general such as food, clothing, and shelter. Higher demand for the basic needs of the people related to zakat will affect the production composition of goods and services in the economy, because it will bring the allocation of resources towards sectors that are more socially desirable. Then, this will increase allocative efficiency in the economy (Wibisiono 2015).

In an economy that does not have mandatory income transfers and that of a large proportion of the population is poor, the real needs of society are reflected in market demands. Goods and services needed by many people, such as food, shelter, clean water, health, and education, are frequently not produced. If zakat transfers income to the poor, the demand for goods and services of the poor will increase. In this context, it can be seen that the allocative function of zakat which reallocates resources from the rich to the poor is one of the effective ways to fight poverty. Therefore, the effect of zakat in the economy reflected in macro indicators will be related to economic growth, poverty, and inequality which are also tremendeously 
Saputro \& Sidiq | The Role Of Zakat, Infaq and Shadaqah (ZIS) in Reducing Poverty in Aceh Province

good as part of the working system of Islamic macroeconomics. Islamic macroeconomic systems are different from mainstream macroeconomic theories such as Keynesian and neoclassical values.

Then Din (1986) argues regarding to the role of zakat fiscal policy. When the collected zakat funds spent in the form of consumption and production goods, the ratio of consumption goods to production goods can be used as fiscal instrument. During the expansion period, this ratio decline as zakat is spent more on production. Meanwhile, during the recession period, this ratio will increase with zakat expenditure directed at consumer goods, so that it will produce an expansionary effect for recovery. Then, zakat is considered as automatic fiscal stabilizer, in which zakat with fixed rates functions as proportional tax will reduce the impact of multipliers; therefore, it can reduce output fluctuations automatically.

\subsection{Zakat and Poverty}

According to Mulajawan et al., (2016),, the notion of poverty is inseparable from thoughts about the objectives of the existence of Sharia or maqasid sharia. Various Sharia teachings are closely related to poverty matters such as alms, neighbors, and so on. Poor is related to the concept of human needs, especially basic needs. Poverty, according to the Islamic view, is closely related to the concept of human needs consisting of five concepts of basic human needs (five maslahah), including: religion (deen), physical (nafs), reason or knowledge ('aql), descent (nasl), and material welfare (maal).

In the Islamic view, development has an important role in fighting poverty. According to Moslem economists, development according to Islam itself has a broader scope and a longer period. There are at least five characteristics of development, namely; comprehensive covering moral, spiritual and material aspects for human life, human development, physical aspects, and sociocultural environment. There is a balance among economic resources, changes, quantity, and quality with an emphasis on aspects of quality change, and finally the optimization of utilization and resource distribution can occur. Consequently, poverty reduction is moral and social responsibility. In figh, it has been a collective agreement (ijma') that caring for the poor is dissent among Moslem scholars (Sadeq 2006). 


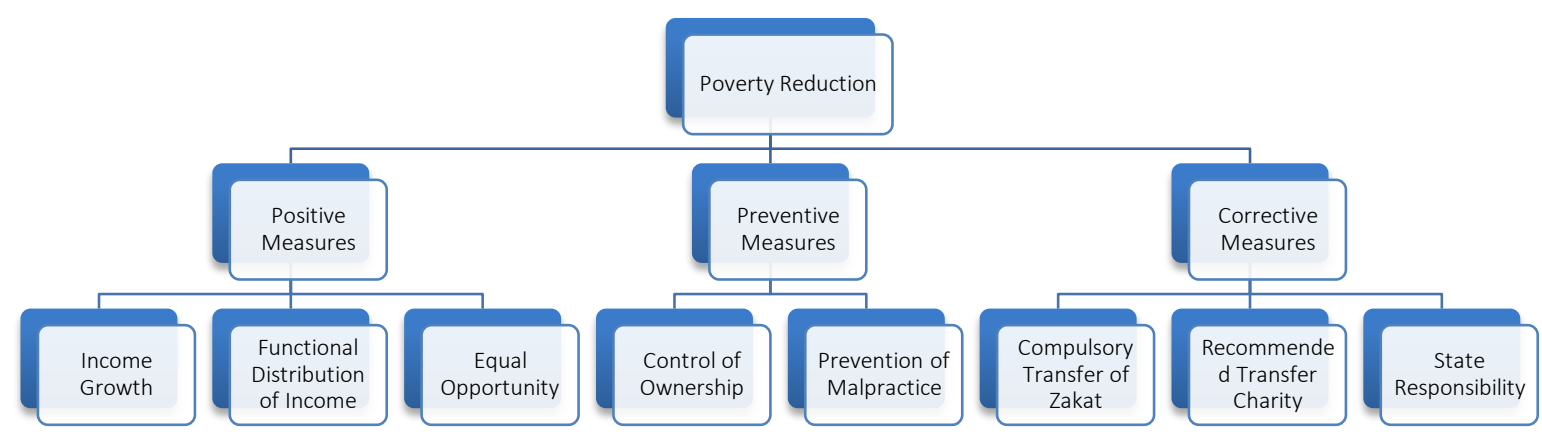

Figure 4. Poverty Reduction According to Islam Source: Sadeq (2006), p.308

The need to reduce poverty has been further emphasized in the Qur'an and the Hadith. However, strategically and technically, it needs consideration from Moslem economists and scholars. In general, poverty reduction can be classified into three objectives, namely:

1. To formulate a series of policies to reduce certain forms of poverty;

2. To provide a guaranteed life in a decent life or to adopt a fair income distribution system. Guarantees for a decent standard of living are not only setting levels of drinking wages, but also including more comprehensive things, such as guarantees of minimum income, health services, education access, and economic and financial resources access;

3. To prepare a redistribution instrument that is under Islamic principles and implement it. There are at least two poverty reduction instruments agreed by figh experts, namely inheritance law and zakat.

\subsection{Zakat and Economic Growth}

According to Metwally (1995), zakat on assets that are productive but not productive will encourage their owners to produce it if they are not willing their wealth to be consumed by zakat. The level of zakat on assets that is not or less productive represents the opportunity cost of investing. On the other hand, the zakat will make the economy go round. Within the rotation of the economy, employment, income generating, and community welfare. In other words, zakat can be used to control and drive the economy.

Qardhawi (2002) added that zakat has meaning to grow, then the wealth spent on zakat in the micro-economy will grow and in the macro-economy will be able to grow the economy. Zakat is one of the economic instruments which has dimensions of the afterlife and world dimensions, but these two dimensions will not have significant effects on the economy if the 
implementation is not integrated with economic activity. In general, economic growth is measured by a number of indicators. In finding out the effect of zakat on economic growth, zakat can be included in the measurement indicators. Correlation analysis is expected to provide a clear description of the relation between zakat and growth. Thus, zakat can be integrated into financial system and be contributed to economic activities in order to achieve sustainable development.

Moslem economists believe that zakat invested in accordance with overall production priorities will benefit the poor in particular and the economy in general, namely through the multiplier effect on employment and income. Zakat will gradually eliminate poverty and reduce the price turnover in a numer of people. As a result, employment and income will increase in the economy which finally increases the living standards of people, and ultimately will increase the aggregate volume of zakat collected, which in turn, will positively affect the rate of economic growth in terms of poverty reduction, unemployment and inflation rates reduction.

\subsection{Zakat and Human Development Index}

According to Susmodiningrat (2002), zakat is part of the mustahik empowerment efforts which can be seen from three sides. The first is making an atmosphere or climate which allows people to develop their potential (enabling). This means, every human being, mustahik, has the potential to be developed and no mustahik is completely powerless. Therefore, empowerment is an effort to build, encourage, motivate, and raise awareness of its potential and strive to develop it.

The second, reinforcing the potential power of the mustahik (empowering). This reinforcement includes concrete steps, and involves providing various inputs, as well as opening access to various opportunities which only make mustahik have power. As with education, zakat is able to change fiscal conditions through mustahik knowledge and skills. Thus, the quality of labor and the quantity of work can be offered. It is expected that by increasing the quality and quantity of labor could boost productive sectors. The third, empowering in the sense of protecting. This means that in the process of empowerment, it should make the weak mustahik in the powerlessness to become strong.

Finally, the concept of empowerment in zakat is applied by the Amil Zakat Agency (BAZ) and the Amil Zakat Institution (LAZ) as the institutions which play a role in the people's economic development and empowerment sustainably. Basically, the concept of zakat applied in the management of 
zakat has three main dimensions, specifically spiritual dimension, social dimension, and economic dimension. These three dimensions are related to the parameters of human development which consist of health, education, and decent living standard. Therefore, the zakat managed by the institutions seems to play a role and becomes one of the instruments that supports human development.

\subsection{Review of Related Research}

Researches on zakat and poverty have been done by practitioners and academics with various kinds of findings. Some studies have found a significant effect of zakat on poverty, but there are findings that show the opposite.

Nisthar \& Nufile (2017), in their research examined the relation between natural poverty and the collection of zakat and GDP in Malaysia. The results of their research reveal that there is a negative relation between poverty and zakat collection and there is a positive relation between GDP and zakat collection. Thus, every increase in zakat collection can reduce poverty and increase real growth in Malaysia. Kareem \& Bankole (2016), in their research entitled zakat, poverty reduction, and inculsive growth in Nigeria show that the more zakat given to poverty reduction, the better the welfare that occurs in Nigeria, meaning that an increase in zakat on the poverty reduction will lead to an increase in community welfare. It is similar to the research conducted Rédha et al., (2016) which examined the effect of collecting zakat funds in reducing poverty in Algeria. The results show that the Algerian zakat fund can help make new businesses that have effect on reducing unemployment and poverty, but the contribution is still slight.

However, in contrast, the results of research conducted by Khasandy \& Badrudin (2019) which examined the effect of zakat on economic growth, HDI, poor population presets, and the gini index are different. The results of their research reveal that zakat in Indonesia does not affect economic growth and social welfare. This shows that zakat in Indonesia does not have a large role in economic growth and social welfare. Similar findings are found in the research done by Nurjanah et al., (2019), regarding the effect of economic growth and distribution of zakat funds on poverty in three districts in West Java Province. The results of their research show that partial distribution of zakat funds does not have negative and insignificant effect on the number of poor people. 


\section{Methodology}

\subsection{Data}

The data used in this study include exogenous latent variables consisting of ZIS $\left(X_{1}\right)$ with ZIS Acceptance indicators $\left(X_{1.1}\right)$ and ZIS Distribution $\left(X_{1.2}\right)$. In addition, endogenous latent variables consisting of Education $\left(Y_{1}\right)$ with the indicators of Rough Participation Rate (APM) indicators $\left(Y_{1.1}\right)$ and Pure Participation Rate (APM) $\left(Y_{1.2}\right)$, Health $\left(Y_{2}\right)$ with the indicators of Number of Health Centers $\left(Y_{2.1}\right)$ and Number of Health Workers $\left(Y_{2.2}\right)$, HDI $\left(Y_{3}\right)$ with Life Expectancy indicators $\left(Y_{3.1}\right)$, Literacy Rate $\left(Y_{3.2}\right)$, School Expectation Rate $\left(Y_{3.3}\right)$, and Expenditure $\left(Y_{3.4}\right)$, Economic Growth $\left(Y_{4}\right)$ and Poverty $\left(Y_{5}\right)$ with the indicators of Poor Population $\left(Y_{5.1}\right)$, Poverty Depth Index $\left(Y_{5.2}\right)$, and Poverty Severity Index $\left(Y_{5.3}\right)$ in 23 Regencies/Cities of Aceh in 2011-2018 (184 data). The data were collected within a certain period of the sample.

The source of this research data, data of poverty, GRDP, Health, and HDI were obtained from the official website of the Central Bureau of Statistics (BPS; Education data were obtained from the official website of the Ministry of Education and Culture; and ZIS Receipt and Distribution data were obtained from the National Zakat Board (BAZNAS) of Aceh, Baitul Mal Aceh.

\subsection{Methodology}

According to Hair et al., (2013), Structural Equation Modeling is a multivariate technique that combines aspects of analytical factors and pathways, which allows researchers to simultaneously examine the relation between manifest variables and latent variables, and between latent variables. There are various methods used when developing SEM; one of which is partial least square (PLS). PLS in SEM can handle all types of data from non-parametric to parametric with minimal assumptions about the characteristics of the data to develop or to construct a theory. Testing by using SEM PLS aims to maximize the explanation of endogenous latent contstruct variants (ependent variables) and minimize unexplained variants.

In terms of latent variables formed in SEM PLS, the indicators can be either reflective or formative. In this study, the reflective indicators are manifesto indicators of the construct and in accordance with classical test theory that assumes that the variance in the measurement of latent variables is the function of true score added by error (Ghozali \& Latan, 2015). 


\subsection{Model Development}

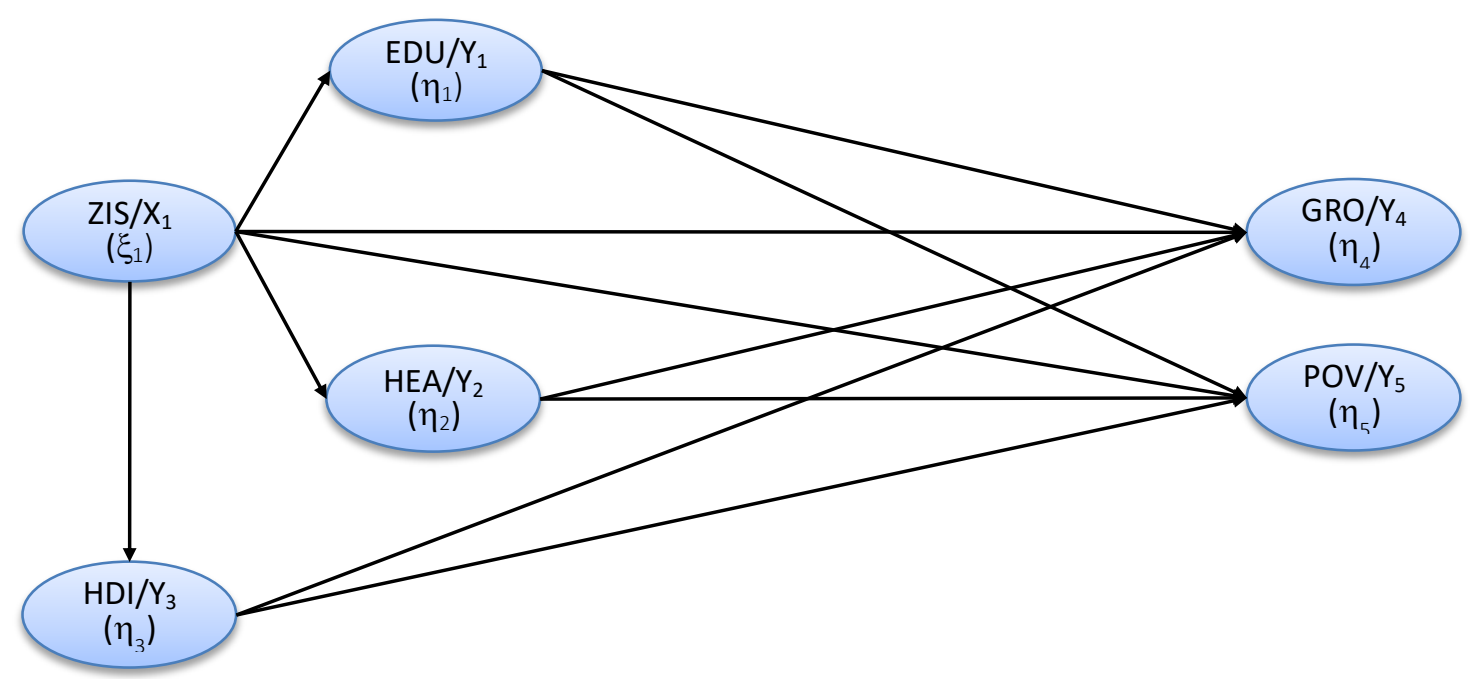

Figure 5. Path Diagram

Based on the path diagram in the figure above, the structural equation is obtained for the measurement model and the structural equation for the measurement model is as follows:

\subsubsection{Equation Outer Model}

Endogenous Variabel 1 (Reflective): Education $\left(Y_{1}\right)$

$Y_{1.1}=\lambda Y_{1.1} \eta_{1}+\varepsilon Y_{1.1}$

$Y_{2.1}=\lambda Y_{2.1} \eta_{1}+\varepsilon Y_{2.1}$

Endogenous Variabel 2 (Reflective): Health $\left(\mathrm{Y}_{2}\right)$

$Y_{2.1}=\lambda Y_{2.1} \eta_{2}+\varepsilon Y_{2.1}$

$Y_{2.2}=\lambda Y_{2.2} \eta_{2}+\varepsilon Y_{2.2}$

Endogenous Variabel 3 (Reflective): HDI $\left(Y_{3}\right)$

$Y_{3.1}=\lambda Y_{3.1} \eta_{3}+\varepsilon Y_{3.1}$

$Y_{3.2}=\lambda Y_{3.2} \eta_{3}+\varepsilon Y_{3.2}$

$Y_{3.3}=\lambda Y_{3.3} \eta_{3}+\varepsilon Y_{3.3}$

$Y_{3.4}=\lambda Y_{3.4} \eta_{3}+\varepsilon Y_{3.4}$

Endogenous Variabel 4 (Reflective): Economic Growth $\left(\mathrm{Y}_{4}\right)$

$Y_{4}=\lambda Y_{4} \eta_{4}+\varepsilon Y_{4}$

Endogenous Variabel 5 (Reflective): Poverty $\left(\mathrm{Y}_{5}\right)$ 
Saputro \& Sidiq | The Role Of Zakat, Infaq and Shadaqah (ZIS) in Reducing Poverty in Aceh Province

$Y_{5.1}=\lambda Y_{5.1} \eta_{5}+\varepsilon Y_{5.1}$

$Y_{5.2}=\lambda Y_{5.2} \eta_{5}+\varepsilon Y_{5.2}$

$Y_{5.3}=\lambda Y_{5.3} \eta_{5}+\varepsilon Y_{5.3}$

Exogenous Variable 1 (Reflective): ZIS $\left(\mathrm{X}_{1}\right)$

$X_{1.1}=\lambda X_{1.1} \xi_{1}+\delta X_{1.1}$

$X_{1.2}=\lambda X_{1.2} \xi_{1}+\delta X_{1.2}$

\subsubsection{Equation of the Inner Model}

Mathematically, it can be written as follows:

$\eta_{1}=f\left(\xi_{1,}\right)$

$\eta_{2}=f\left(\xi_{1,}\right)$

$\eta_{3}=f\left(\xi_{1,}\right)$

$\eta_{4}=f\left(\xi_{1}, \eta_{1}, \eta_{2}, \eta_{3}\right)$

$\eta_{5}=f\left(\xi_{1}, \eta_{1}, \eta_{2}, \eta_{3}\right)$

Then, the functions are explained as follows:

$\eta_{1}=\gamma_{11} \xi_{1}+\zeta_{1}$

$\eta_{2}=\gamma_{12} \xi_{1}+\zeta_{2}$

$\eta_{3}=\gamma_{13} \xi_{1}+\zeta_{3}$

$\eta_{4}=\gamma_{14} \xi_{1}+\gamma_{24} \eta_{1}+\gamma_{34} \eta_{2}+\gamma_{44} \eta_{3}+\zeta_{4}$

$\eta_{5}=\gamma_{15} \xi_{1}+\gamma_{25} \eta_{1}+\gamma_{35} \eta_{2}+\gamma_{45} \eta_{3}+\zeta_{5}$

Where:

$\lambda=$ Loading Factor; $\varepsilon, \delta=$ Residual between latent variabels and indicators; $\xi$ $=$ Laten Exogenous Variables; $\eta=$ Laten Endogenous Variables; $\gamma=$ Path Coefficient; $\zeta=$ Residual Model; $Y_{1.1}=$ Rough Participation Rate; $Y_{1.2}=$ Pure Participation Rate; $Y_{2.1}=$ Number of Community Health Center; $Y_{2.2}=$ Number of Health Workers; $Y_{3.1}=$ Life Expectancy; $Y_{3.2}=$ Literacy Rate; $Y_{3.3}=$ Old School Expectation Rate; and $Y_{3.4}=$ Expenditure; $Y_{4}=$ Economics Growth; $Y_{5.1}$ $=$ Percentage of Poor Population; $Y_{5.2}=$ Poverty Depth Index; $Y_{5.3}=$ Poverty Severity Index; $X_{1.1}=$ Acceptance of ZIS; $X_{1.2}=$ Distribution of ZIS. 


\section{Results and Analysis}

\subsection{Results}

\subsubsection{Assessing the Outer Model}

The Outer Model analysis specifies how each block of indicators relates to the latent variable. Outer model uses two types of testing namely; Validity and Reliability Test. Validity testing is also divided into two tests, namely the validity test on the reflective indicator and the validity test on the formative indicator.

\subsubsection{Validity Test}

Constructions with reflective indicators assume that the covariance between model measurements is explained by the variant that manifests the construct domain. The direction of the indicator is from construct to indicator. The validity test of reflective indicators uses three tests namely Convergent Validity, Discriminant Validity, and Average Variance Extracted (AVE). The test results in this study are as follows:

\subsubsection{Convergent Validity}

Convergent validity test is related to the principle that the gauges (manifest variables) of a construct should be highly correlated. The convergence validity test of the reflective indicator using the SmartPLS 3.2.8 program can be seen from the loading factor value for each construct indicator. The rule of thumb usually used to assess convergent validity is that the loading factor value must be $\geq 0.50$. 
Table 1. Outer loading

\begin{tabular}{|c|c|c|c|c|c|c|}
\hline \multicolumn{7}{|c|}{ OUTER LOADING } \\
\hline & $X_{1}$ & $Y_{1}$ & $Y_{2}$ & $Y_{3}$ & $Y_{4}$ & $Y_{5}$ \\
\hline$\overline{X_{1.1}}$ & 0.959 & & & & & \\
\hline$X_{1.2}$ & 0.958 & & & & & \\
\hline$Y_{1.1}$ & & 0.945 & & & & \\
\hline$Y_{1.2}$ & & 0.892 & & & & \\
\hline$Y_{2.1}$ & & & 0.808 & & & \\
\hline$Y_{2.2}$ & & & 0.840 & & & \\
\hline$Y_{3.1}$ & & & & 0.804 & & \\
\hline$Y_{3.2}$ & & & & 0.729 & & \\
\hline$Y_{3.3}$ & & & & 0.653 & & \\
\hline$Y_{3.4}$ & & & & 0.780 & & \\
\hline$Y_{4}$ & & & & & 1,000 & \\
\hline$Y_{5.1}$ & & & & & & 0.628 \\
\hline$Y_{5.2}$ & & & & & & 0.806 \\
\hline$Y_{5.3}$ & & & & & & 0.833 \\
\hline
\end{tabular}

Source: SmartPLS 3.2.8 Calculation

Outer Loading is used to measure the convergence validity of the measurement model (instrument). From the results of data processing with PLS in the table above, it can be seen that the majority of the indicators of each loading value meets the convergent vallidty because all loading factors is $>0.50$. Therefore, it can be concluded that the convergence validity of the endogenous construct group $X_{1}(Z I S), Y_{1}$ (Education), $Y_{2}$ (Health), $Y_{3}$ (HDI), and $\mathrm{Y}_{5}$ (Poverty) is valid.

\subsubsection{Discrimant Validity}

The measurement model with reflective indicators is assessed based on cross loading measurements with constructs. If the correlation of constructs with measurement items is greater than other construct measurements, this means that latent constructs predict their block size better than other block sizes. 
Table 2. Cross loading Value

\begin{tabular}{|c|c|c|c|c|c|c|}
\hline \multicolumn{7}{|c|}{ CROSS LOADING } \\
\hline & $\mathrm{X}_{1}$ & $\mathrm{Y}_{1}$ & $\mathrm{Y}_{2}$ & $\mathrm{Y}_{3}$ & $\mathrm{Y}_{4}$ & $\mathrm{Y}_{5}$ \\
\hline $\mathrm{X}_{1.1}$ & 0.959 & -0.349 & 0.462 & 0.571 & 0.626 & -0.138 \\
\hline $\mathrm{X}_{1.2}$ & 0.958 & -0.298 & 0.465 & 0.580 & 0.624 & -0.129 \\
\hline $\mathrm{Y}_{1.1}$ & -0.336 & 0.945 & -0.465 & -0.223 & -0.407 & 0.113 \\
\hline$Y_{1.2}$ & -0.278 & 0.892 & -0.355 & -0.143 & -0.278 & -0.030 \\
\hline$Y_{2.1}$ & 0.354 & -0.485 & 0.808 & -0.075 & 0.575 & -0.035 \\
\hline$Y_{2.2}$ & 0.439 & -0.271 & 0.840 & 0.457 & 0.542 & -0.216 \\
\hline$Y_{3.1}$ & 0.450 & -0.343 & 0.188 & 0.804 & 0.484 & -0.279 \\
\hline$Y_{3.2}$ & 0.454 & -0.249 & 0.194 & 0.729 & 0.288 & -0.321 \\
\hline$Y_{3.3}$ & 0.432 & 0.034 & 0.125 & 0.653 & 0.315 & -0.195 \\
\hline$Y_{3.4}$ & 0.450 & -0.011 & 0.217 & 0.780 & 0.303 & -0.323 \\
\hline$Y_{4}$ & 0.652 & -0.382 & 0.676 & 0.473 & 1,000 & -0.234 \\
\hline$Y_{5.1}$ & -0.160 & -0.048 & -0.057 & -0.300 & -0.123 & 0.628 \\
\hline$Y_{5.2}$ & -0.100 & 0.125 & -0.139 & -0.305 & -0.209 & 0.806 \\
\hline$Y_{5.3}$ & -0.063 & 0.040 & -0.154 & -0.257 & -0.195 & 0.833 \\
\hline
\end{tabular}

Source: SmartPLS 3.2.8 Calculation

Based on the results of the cross loading estimation above, it shows that each indicator in the construct has a greater loading factor value than other construct values. Therefore, this shows that each indicator is valid to explain its respective endogenous construct and proves that the discriminant validity of all indicators are valid.

\subsubsection{Construct Reliability}

The next stage is testing the consistency of measurements (reliability) with Average Variance Extract (AVE) and Composite Reliability (CR). High reliability indicates that indicators have high consistency in measuring latent constructs. Reliability can be known through the value of Composite Reliability (CR) and Average Variance Extracted (AVE). Composite Reliability is regarded to be good if it has a value of $\geq 0.70$. AVE value is considered good if it has a value of $\geq 0.05$ (Ghozali 2014). The results of the AVE and CR tests are shown in the following table:

Table 3. Reliability Value of Exogenous Constructs to Endogenous Constructs

\begin{tabular}{|c|c|c|c|}
\hline Exogenous Constructs & $\begin{array}{c}\text { Composite } \\
\text { Reliability }\end{array}$ & $\begin{array}{c}\text { Average Variance } \\
\text { Extract }\end{array}$ & Conclusion \\
\hline $\mathrm{X}_{1}$ (ZIS) & 0.958 & 0.919 & Reliable \\
\hline $\mathrm{Y}_{1}$ (Education) & 0.915 & 0.844 & Reliable \\
\hline $\mathrm{Y}_{2}$ (Health) & 0.809 & 0.680 & Reliable \\
\hline $\mathrm{Y}_{3}$ (HDI) & 0.831 & 0.553 & Reliable \\
\hline $\mathrm{Y}_{4}$ (Economic Growth & 1.000 & 1.000 & Reliable \\
\hline $\mathrm{Y}_{5}$ (Poverty) & 0.803 & 0.580 & Reliable \\
\hline
\end{tabular}

Source: SmartPLS 3.2.8 Calculation 
Based on the results of the validity and reliability tests of the measurement model, it can be concluded that all observed variables is valid in measuring latent variables and the reliability of the measurement model is good as well. This shows that the indicator is reliable in constructing the latent variable constructs.

\subsubsection{Structural Model Evaluation (Inner Model)}

After testing the outer model, evaluation of the structural model (inner model) is then performed to see the compatibility between the constructs in the structural model and the predictive ability of the model. Structural model is evaluated by using path coefficients or $t$-values and $p$-values for each path to test the significance of the constructs in the structural model.

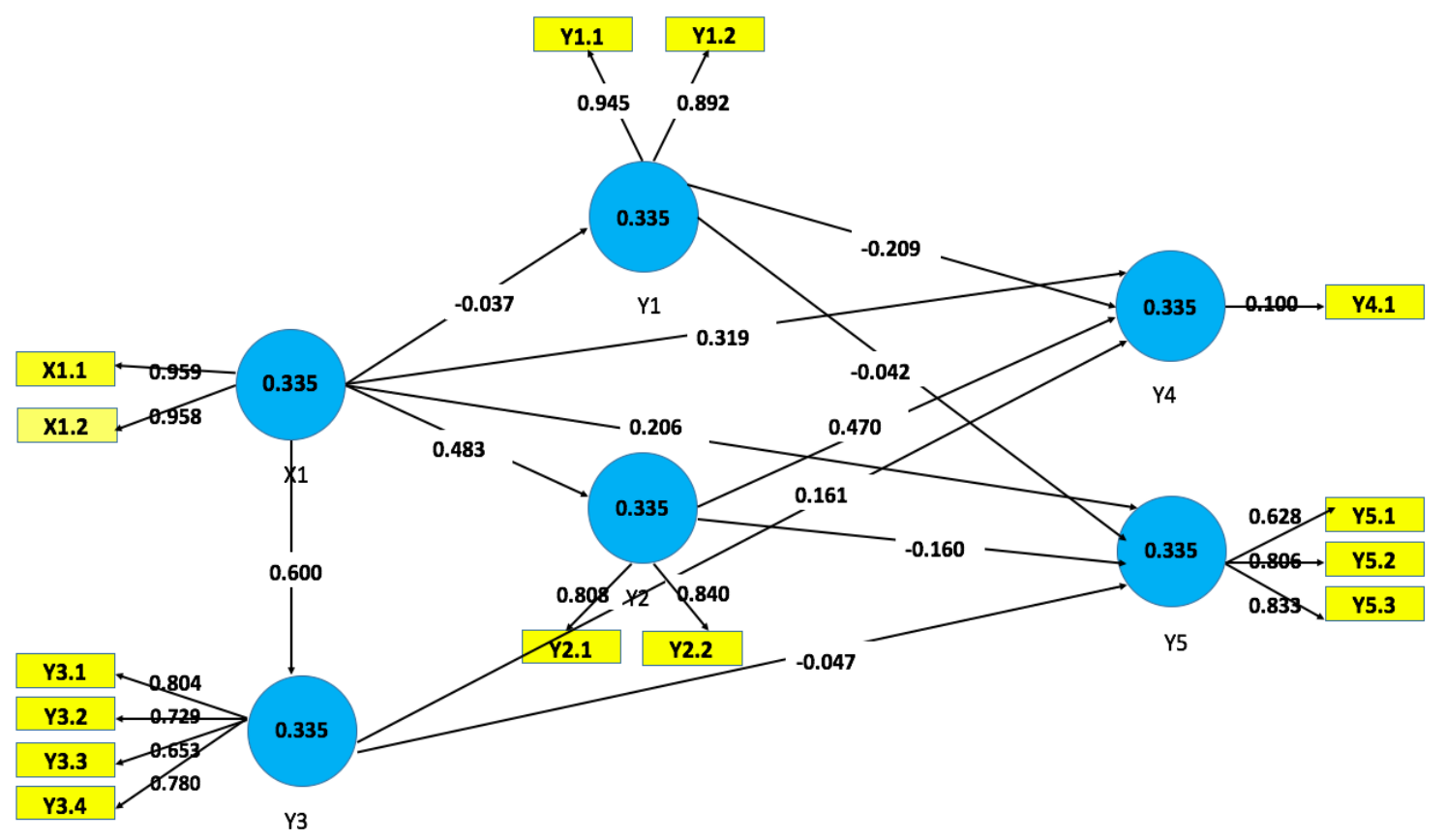

Figure 6. The Analyzed Reseacrh Model

\subsubsection{The Relation between Exogenous Constructs and Endogenous Constructs}

Evaluation of structural models is in the form of relation between exogenous constructs and endogenous constructs that can be seen through statistical ttest or $p$-value and structural path co-affinity. If the value of t-statistics is $>t-$ table and if the value of $p$-value is $<\alpha 0.05$, it can be concluded that there is an effect between exogenous and endogenous constructs. The results of data decreasing that can explain the relation between exogenous constructs and endogenous constructs can be seen in the table below: 
Table 4. Path Coefficient

\begin{tabular}{|c|c|c|c|}
\hline & Original Sample & $p$-Value & Conclusion \\
\hline$X_{1}>Y_{1}$ & -0.337 & 0.000 & Rejected \\
\hline$X_{1}>Y_{2}$ & 0.483 & 0.000 & Accepted \\
\hline$X_{1}->Y_{3}$ & 0.600 & 0.000 & Accepted \\
\hline$X_{1}>Y_{4}$ & 0.319 & 0.000 & Accepted \\
\hline$X_{1}->Y_{5}$ & 0.206 & 0.045 & Rejected \\
\hline
\end{tabular}

Source: SmartPLS 3.2.8 Calculation

Table 5. Total Indirect Effect

\begin{tabular}{|l|r|r|r|}
\hline \multicolumn{1}{|c|}{ Variable } & \multicolumn{1}{c|}{ Original Sample } & \multicolumn{1}{c|}{ p-value } & Conclusion \\
\hline$X_{1} \rightarrow Y_{4}$ & 0.333 & 0.000 & Accepted \\
\hline$X_{1} \rightarrow Y_{5}$ & -0.345 & 0.000 & Accepted \\
\hline
\end{tabular}

Source: SmartPLS calculation 3.2.8

Table 6. Indirect Specific Effect

\begin{tabular}{|c|c|c|c|}
\hline Variable & Original Sample & $\mathrm{p}$-Value & Conclusion \\
\hline$X_{1}->Y_{1}->Y_{4}$ & 0.010 & 0.604 & Rejected \\
\hline$X_{1}>Y_{2}->Y_{4}$ & 0.227 & 0.000 & Accepted \\
\hline$X_{1}>Y_{3}->Y_{4}$ & 0.097 & 0.017 & Accepted \\
\hline$X_{1}>Y_{1}>Y_{5}$ & 0.014 & 0.621 & Rejected \\
\hline$X_{1}>Y_{2}>Y_{5}$ & -0.077 & 0.073 & Rejected \\
\hline$X_{1}>Y_{2}>Y_{5}$ & -0.282 & 0.000 & Accepted \\
\hline
\end{tabular}

Source: SmartPLS 3.2.8 Calculation

\subsection{Analysis}

\subsubsection{The Effect of ZIS on Education}

Education sector is one of the superior programs of Baitul Mal Aceh. This education program consists of Full Scholarship, Sustainable Education Assistance, and One-time Assistance. The three programs target elementary to diploma education levels by providing full assistance (full scholarship), assistance in carrying out compulsory education (Sustainable Education Assistance), and assistance for Acehnese students who are doing their final assignments (One-Time Assistance).

The analysis results show the original sample/coefficient value of $(-0.337)$ and are significant at a probability value of less than alpha of $5 \%(0,000)$. It is assumed that there is a direct, positive, and significant effect of ZIS on education, but the results show a negative and significant direct effect of ZIS 
on education or distribution of ZIS done by Baitul Mal Aceh in the education program to reduce poverty in Aceh. The analysis results are in accordance with the condition of education in Aceh that is quite ironic. According to data from the Ministry of Education and Culture, it is found that the quality of teachers and graduates in Aceh in 2015 was ranked 32 out of 34 existing provinces.

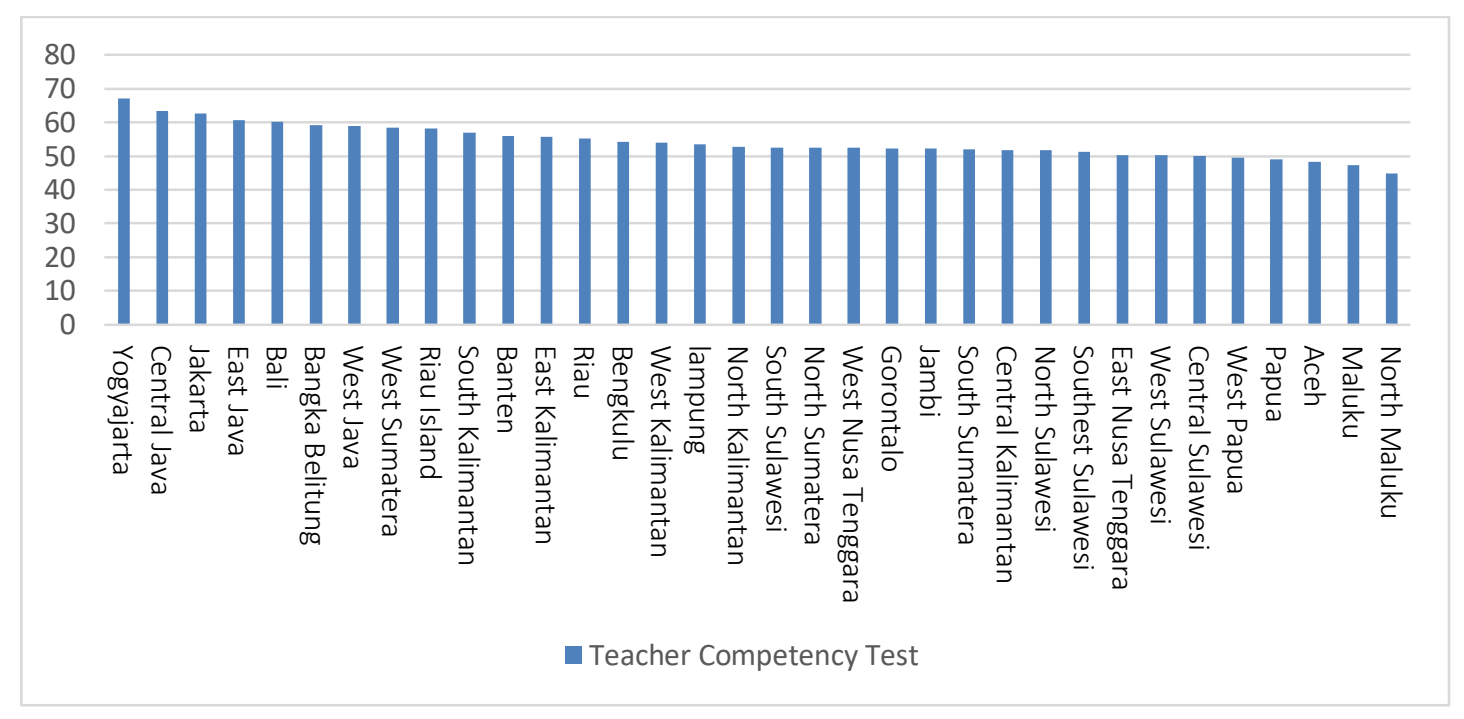

Figure 7. Teacher Competency Test

Source: Ministry of Education and Cultrue

Figure 7 shows the teacher competency test that illustrates how the quality of teachers in all provinces in Indonesia in 2015. It can be seen that the quality of the best teachers occupied by Yogyakarta with a value of 67.02 and the lowest quality of teachers occupied by North Maluku with a value of 44 , 79. Aceh was ranked 32 out of 34 provinces in Indonesia in terms of quality of teachers with a value of 48.33. This value is even greater than West Papua and Papua. This illustrates how teachers as an important component in improving education have not been able to present education in Aceh. 


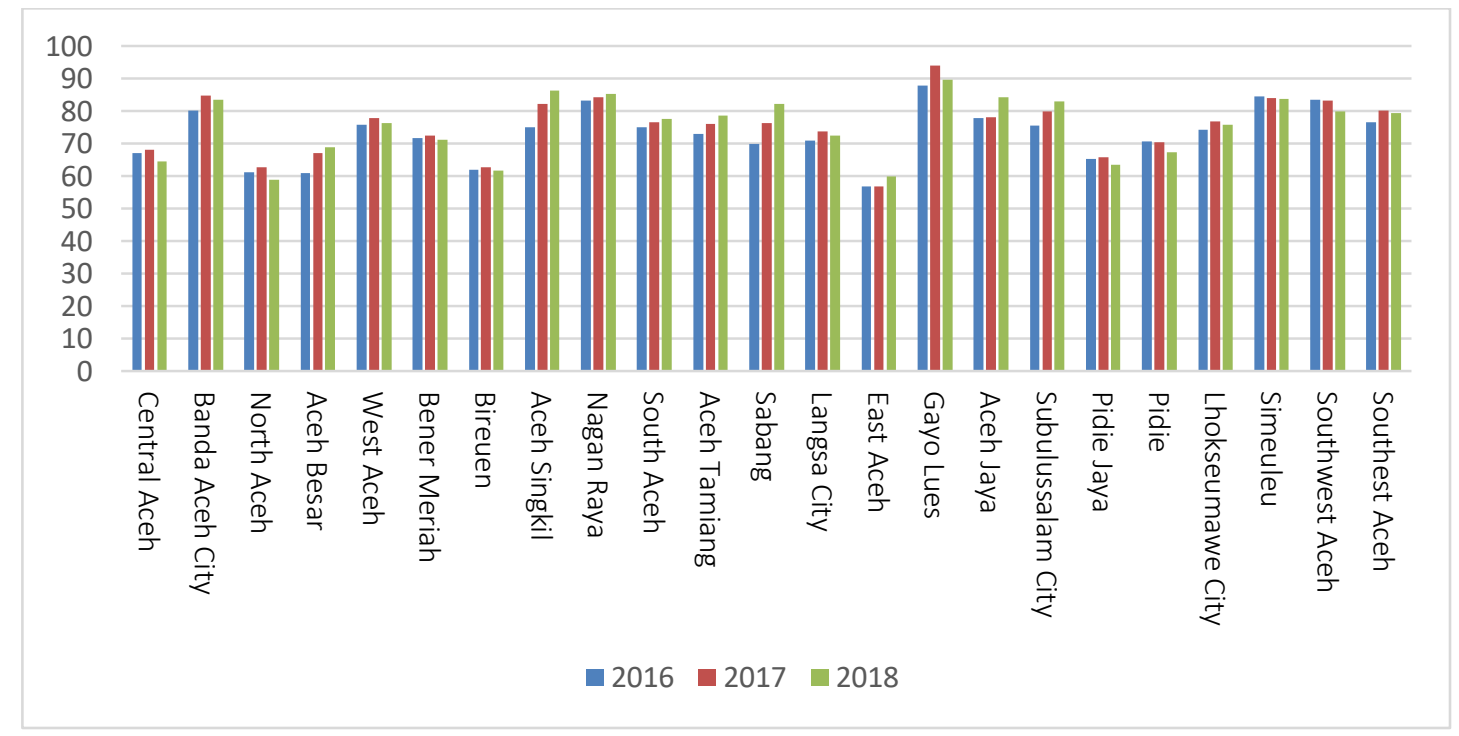

Figure 8. Rough Participation Rate in Aceh Regencies/Cities (2016-2018) Source: Ministry of Education and Cultrue

The next is the Rough Participation Rate (APK) as an illustration to find out the number of students who study at certain levels of education. It can be seen in Figure 8 that 13 out of 23 regencies/Cities in Aceh have Rough Participation (APK) values that tend to decrease, namely Central Aceh, North Aceh, Banda Aceh City, West Aceh, Bener Meriah, Biruen, Langsa City, Pidie Jaya, Pidie, Lhoksemawe City, Simeuleu, Southwest Aceh, and Southeast Aceh. Not only experiences the decline, some of the regencies also have APK values that are far from the APK value nationally or compared to other provinces in Indonesia. It also shows how population participation in education in several regencies in Aceh is decreasing every year.

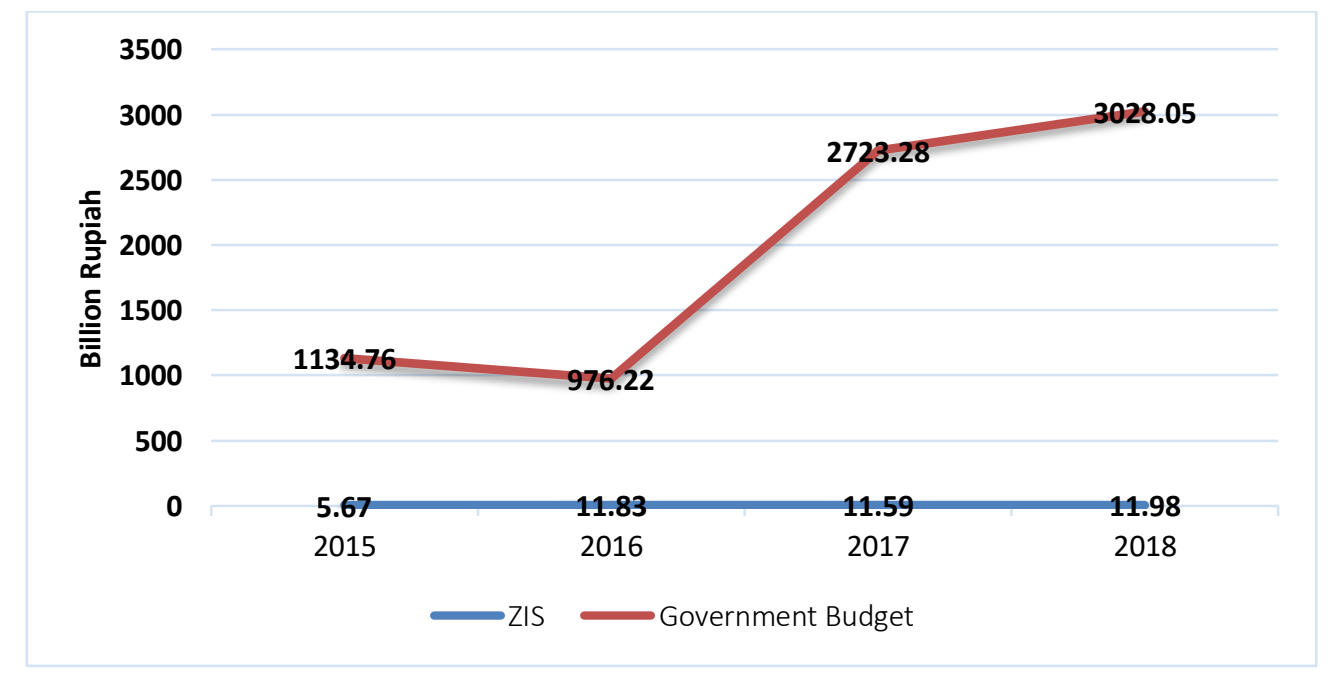

Figure 9. Budget For Education From ZIS and Provincial Government Source: Baitul Mal Aceh \& Regional Educatioan Balance 
Saputro \& Sidiq | The Role Of Zakat, Infaq and Shadaqah (ZIS) in Reducing Poverty in Aceh Province

Therefore, if connected to zakat distribution program carried out by Baitul Mal Aceh in the education sector, the nominal distribution which is not as much as the Aceh provincial government budget for the education sector has not been able to improve the quality of Aceh's education. The data from Figure 4.4 above shows how the significant difference is related to the presentation of ZIS and the budget of Aceh Government, especially in its efforts to improve education in Aceh. ZIS distribution conducted by Baitul Mal Aceh is not as much as that done by Aceh government. Thus, it can be stated that it also does not have a large contribution in efforts to improve education in Aceh, even though the realization of ZIS distribution in education program continues to increase every year. It happens because even a large government budget has not been able to improve education in Aceh, but on the contrary, it is even decreasing because of poor teacher quality and population participation in education in Aceh.

The results of this study are in line with the research conducted by by Akram \& Afzal (2014) regarding the dynamic role of zakat in reducing poverty in Pakistan. The results show that the distribution of zakat done by the Pakistani government does not have significant effect on education both in short and long term. Hence, this present study shows that the distribution of zakat is not able to improve education in Pakistan. Therefore, the researchers provide recommendations in order that the Pakistani government can ensure free education for children and young adults and can establish vocational institutions in remote and urban areas.

\subsubsection{The Effect of ZIS on Health}

ZIS has a positive and significant effect on Health in Aceh. Health is the part of social programs in Baitul Mal Aceh and is one of the leading programs. There are three health assistance programs in the social program, namely Lifelong Ummah Compensation Assistance, Medical Equipment Aid, and Funds Assistance for Cancer and Thalesmia Patients. These assistances are addressed to people who do not have wealth and income, who are relatively old and sick. The assistances are provided in the form of monthly compensation of Rp. 300,000; medical assistance program is in the form of wheelchairs, walking aids and hearing aids; and Funds Assistance Program for Cancer and Thalesmia Patients is addressed to patients from poor families through financial support in undergoing routine checks to hospital, and accommodation costs during the medical examination. Hopefully, it can help the community to be able to live a good life.

The analysis shows the original sample/coefficient value of $(0.483)$ and is significant at a probability value of less than alpha of $5 \%(0,000)$. This reveals 
that the distribution of ZIS conducted by Baitul Mal Aceh has a direct effect in improving the quality of public health. This result is also in line with social sub-programs in health funding assistance that is addressed to someone who is categorized in need of health assistance both through adequate health facilities and infrastructures, and Baitul Mal Aceh can meet all of them.

This finding is also in accordance with the research conducted by Suprayitno et al., (2017), regarding the effect of zakat on human development in 5 regions in Malaysia. The results show that the more zakat funds collected, the stronger it is for zakat to play an important role in social life, social welfare, and economic development in its efforts to replace the role of the government budget in achieving it. In addition, there are programs implemented such as programs to meet basic needs, ongoing programs both physical and psychological and spiritual needs. Besides, one of the programs is health and insurance implemented for short and long term.

\subsubsection{The Effect ZIS on HDI (Human Development Index)}

ZIS has a positive and significant effect on HDI in Aceh. If the components of $\mathrm{HDI}$ are explained, the components generally are Education, Health, and Economy. In education, Baitul Mal Aceh supports the existence of educational assistance in the form of scholarship. In its social programs, it supports life for mustahik who are economically weak, sick, and do not have family; provides medical aid to support the life of mustahik to be better; and provides assistance for cancer and thalesma sufferers to be able to obtain health facilities and infrastructure to get recovered. Furthermore, in economy, in terms of spending, it is done by directing mustahik not to be fully consumptive so that they are able to be economically independent and turn mustahik into muzzaki.

The analysis shows the original sample/coefficient value of $(0.600)$ and is significant at a probability value of less than alpha $5 \%(0,000)$. This shows that the distribution of ZIS carried out by Baitul Mal Aceh has a direct effect in improving the quality of the community. The presentation of the above programs shows how Baitul Mal Aceh through Education, Health and Economy programs, which support the quality of Aceh community is getting better. Thus, the results found are in accordance with the objectives of the Baitul Mal Aceh programs which are related to improving the quality of Aceh community.

This present research is also in line with what was done by Rédha et al., (2016) who examined the effect of zakat fund financing in reducing poverty in Algeria. The results show that financing through the distribution of zakat 
funds made to projects undertaken has a positive and significant effect on increasing HDI. Hence, an increase in new projects carried out through zakat funds will improve the quality of the community (HDI).

\subsubsection{The Effect of ZIS on Economic Growth}

ZIS has a positive and significant effect on Economic Growth. Baitul Mal Aceh supports economic independence for every mustahik and it hopefully can have an effect on the economy in Aceh. The program in economic empowerment that is carried out by Baitul Mal Aceh is in the form of skill training for Acehnese, provision of venture capital, and assistance provision for working equipment for businesses that have started their businesses. The analysis results on the effect of ZIS on Economic Growth in Aceh reveal the original sample/coefficient value of $(0.319)$ and are significant at a probability value of less than alpha of $5 \%(0,000)$ on directly effect and original sample/coefficient value of $(0.333)$ and are significant at a probability value of less than alpha of $5 \%(0,000)$ on indirectly effect. This shows that the distribution of zakat funds carried out by Baitul Mal Aceh through mustahik economic development program in particular, supported by education and health programs, can directly and indirectly increase economic growth in Aceh.

The analysis results on the effect of ZIS through Education on Economic Growth in Aceh show the original sample/coefficient value of (0.010) and are insignificant at a probability value greater than alpha $5 \%$ of $(0.604)$. This shows that the distribution of zakat funds carried out by Baitul Mal Aceh does not have a significant effect on economic growth through the educational program undertaken. This result is also in accordance with the poor condition of education in Aceh that affects the quality of graduates who also describe the community quality, and when associated with productivity, it certainly does not have a significant effect on economic growth in Aceh.

In contrast to the analysis results on the effect of ZIS through Health on Economic Growth, it shows the original sample/coefficient value of $(0.227)$ and are significant at a probability value of less than alpha of $5 \%(0,000)$. This shows that the distribution of ZIS through health programs carried out by Baitul Mal Aceh is done by targetting "all" mustahik who are sick even to mustahik who have serious diseases such as cancer, and by providing medical aid for those in need. Therefore, the health program can make mustahik able to access good health facilities and infrastructure. Besides, this can make mustahik have good health conditions and mustahik who need medical devices can support their activities, so that it can increase mustahik productivity that can support Economic Growth in Aceh. 
Saputro \& Sidiq | The Role Of Zakat, Infaq and Shadaqah (ZIS) in Reducing Poverty in Aceh Province

Other findings on the effect of ZIS through HDI on Economic Growth are also found in which it has a positive and significant effect of ZIS on Economic Growth through HDI. It is proven from the original sample/coefficient value which is of (0.097) and is significant at the probability value which is less than alpha 5\% (0.017). This shows that programs made by Baitul Mal Aceh such as education, health, and community economic empowerment can directly improve the quality of the community, so that it can have an effect on community productivity which then has a multiple effect on economic growth in Aceh.

The results of the present study are also in line with the findings otained by Athoillah (2018), and Mohamed et al., (2019) showing the positive and significant effect of zakat on economic growth. Both studies were conducted in two different countries. Athoillah (2018), conducted a study in Indonesia with a focus on the island of Java, where the results showed that zakat had a positive effect on economic growth; zakat has a negative but not significant effect on unemployment and zakat has a negative and significant effect on poverty. Furthermore, and Mohamed et al., (2019) conducted research in Malaysia in which the results showed that there was a significant relation among zakat, GDP, and poverty. It also showed that there was an important relation between zakat and an increase in GDP which then had a higher effect in inducing poverty reduction.

\subsubsection{The Effect of ZIS on Poverty}

The main objective of Baitul Mal Aceh through its superior programs especially in education, social (health), and economic empowerment, is to make mustahik economically independent so that it can remove mustahik from poverty and is able to become muzzaki. The analysis shows the original sample/coefficient value of (0.206) and is significant at a probability value of less than alpha $5 \%$ (0.045). This reveals that the distribution of ZIS conducted by Baitul Mal Aceh through the community economic empowerment program directly has a positive effect or can increase poverty in Aceh. It is assumed that there is a direct, negative, and significant effect of ZIS on reducing poverty, but the results show a positive and significant direct effect of ZIS on poverty. 


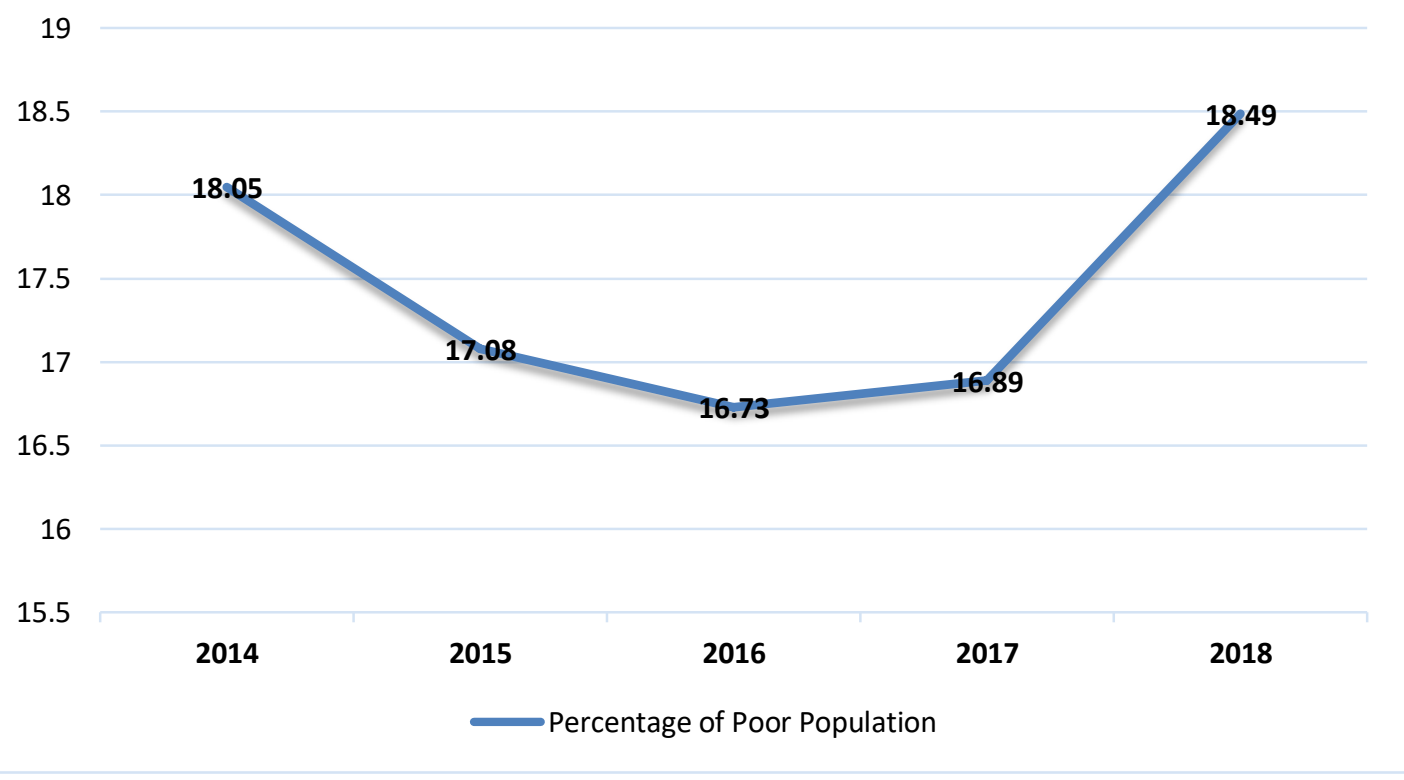

Figure 10. Percantage of Poor People in Aceh Province (2014-2018)

Source: Central Bureau of Statistics of the Republic of Indonesia (BPS)

The data above show the percentage of poor population in Aceh in 20142018. The percentage of poor people during the last 5 years shows fluctuations but it tends to increase. Especially in the period of 2016-2018 which showed a significant increase; even in 2018, it had a greater percentage of poor people than in 2014. Hence, the distribution of ZIS carried out by Baitul Mal Aceh especially in the economic empowerment program could not reduce directly but it is on the contrary. This is because the reality reveals that the percentage of poor people in Aceh has been increasing each year, especially in the last five years. Therefore, it is not easy to make the distribution of ZIS in playing its role to have a large/direct effect on poverty reduction in Aceh, especially not only on the percentage of poor people at the provincial level that continues to increase, but the percentage of poverty in each regency/city of Aceh also increases. 


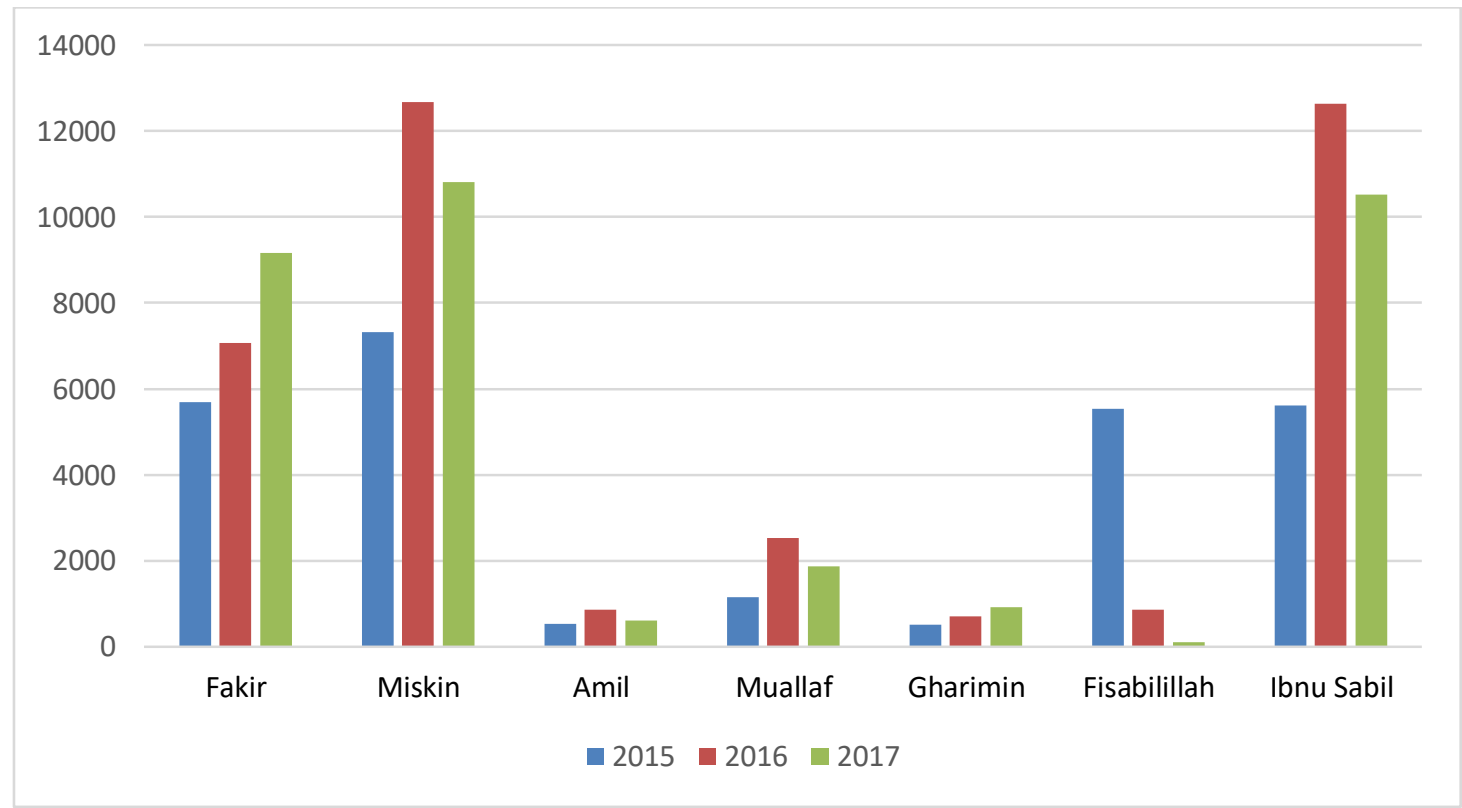

Figure 11. Distribution of Zakat

Source: Baitul Mal Aceh

Besides the problem of a high percentage of the poor population, it is also related to how Baitul Mal Aceh conducts community economic empowerment programs. The data in Figure 4.6 show that the distribution of zakat to asnaf poor people has fluctuations that tend to decrease. The data above also show that the distribution of zakat for Ibn Sabil or someone who is on journey is quite high or even greater than the distribution for asnaf fakir. Therefore, the program to reduce poverty in the province has not yet got the most attention. Thus, it needs a focus on the distribution of zakat distribution to asnaf fakir and poor, especially to asnaf ibnu sabil that naturally is not a resident of Aceh but has a substantial realization of ZIS distribution.

However, the results of other analyzes show that there is an indirect effect of ZIS on poverty, namely the original sample/coefficient value of $(-0.345)$ and is significant at a probability value greater than alpha $5 \%(0,000)$. This reveals that through programs implemented by Baitul Mal Aceh (Education, Health and Economic Empowerment of mustahik), it can indirectly reduce poverty in Aceh.

The next finding shows that the effect of ZIS distribution through Education on Poverty is not found with the original sample/coefficient value of (0.014) and is significant at a probability value greater than alpha $5 \%(0.621)$. In addition, the effect of ZIS through Health on Poverty is also not found with the original sample/coefficient value of $(-0.077)$ and is significant at a probability value greater than alpha $5 \%(0.073)$. This shows that the 
Saputro \& Sidiq | The Role Of Zakat, Infaq and Shadaqah (ZIS) in Reducing Poverty in Aceh Province

distribution of ZIS through education and health programs carried out by Baitul Mal Aceh does not have a significant effect in reducing poverty in Aceh.

It is different from the analysis results on the effect of ZIS through HDI on poverty showing that it has a negative and significant effect, with the original sample/coefficient value of $(-0,282)$ and is significant at a probability value of less than alpha $5 \%(0,000)$. This shows that in order to reduce poverty rates in Aceh, it needs a complete and perfect combination of programs that can have an effect on mustahik. It includes education, health, and economic independence so that mustahik has good quality. When mustahik can access education, good health conditions, and can be economically independent, it can indirectly remove mustahik from the poverty circle through reflection of the mustahik quality illustrated by high (good) HDI components.

Table 7. Percentage of Poor Population in Aceh Province (Regencies/Cities)

\begin{tabular}{lrrrrr}
\hline \multicolumn{1}{c}{ Kab/Kota } & \multicolumn{1}{c}{2014} & \multicolumn{1}{c}{2015} & \multicolumn{1}{c}{2016} & \multicolumn{1}{c}{2017} & \multicolumn{1}{c}{2018} \\
\hline Central Aceh & 16.99 & 17.51 & 16.64 & 16.84 & 15.58 \\
Banda Aceh & 7.78 & 7.72 & 7.41 & 7.44 & 7.25 \\
North Aceh & 19.58 & 19.2 & 19.46 & 19.78 & 18.27 \\
Aceh Besar & 16.13 & 15.93 & 15.55 & 15.41 & 14.47 \\
West Aceh & 23.7 & 22.97 & 21.46 & 20.38 & 19.31 \\
Bener Meriah & 22.45 & 21.55 & 21.43 & 21.14 & 20.13 \\
Bireuen & 16.94 & 16.94 & 15.95 & 15.87 & 14.31 \\
Aceh Singkil & 17.77 & 21.72 & 21.6 & 22.11 & 21.25 \\
Nagan Raya & 20.85 & 20.13 & 19.25 & 19.34 & 18.97 \\
South Aceh & 12.79 & 13.24 & 13.48 & 14.07 & 14.01 \\
Aceh Tamiang & 14.58 & 14.57 & 14.51 & 14.69 & 14.21 \\
Sabang & 17.02 & 17.69 & 17.33 & 17.66 & 16.31 \\
Langsa & 12.08 & 11.62 & 11.09 & 11.24 & 10.79 \\
East Aceh & 15.88 & 15.85 & 15.06 & 15.25 & 14.49 \\
Gayo Lues & 21.43 & 21.95 & 21.86 & 21.97 & 20.7 \\
Aceh Jaya & 16.52 & 15.93 & 15.01 & 14.8 & 14.85 \\
Subulussalam & 19.72 & 20.39 & 19.57 & 19.71 & 18.51 \\
Pidie Jaya & 21.78 & 21.4 & 21.18 & 21.82 & 20.17 \\
Pidie & 20.29 & 21.18 & 21.25 & 21.43 & 20.47 \\
Lhokseumawe & 11.93 & 12.16 & 11.98 & 12.32 & 11.81 \\
Simeuleu & 19.92 & 20.43 & 19.93 & 20.2 & 19.78 \\
Aceh Barat Daya & 17.99 & 18.25 & 18.03 & 18.31 & 17.1 \\
Aceh Tenggara & 13.75 & 14.91 & 14.46 & 14.86 & 14.29 \\
\hline
\end{tabular}

Source: Central Bureau of Statistics of the Republic of Indonesia (BPS) 
Table 7 shows the percentage of poor population in Aceh regencies/ cities during 2014-2018 at the regency and city level. It can be seen that all regencies/cities in Aceh experienced fluctuations but tended to decline. Thus, it can be concluded that the ZIS program that has targets in each regency/city in Aceh is able to reduce poverty indirectly through programs that are held (Education, Health, Economic Empowerment), but it is still at the regency/city scale. Although the percentage of poverty in the regencies/cities in Aceh Province is still in average 11-20\% or in other words, it can be stated that it has a high percentage of poor population.

The results of this study are also in line with the findings made by Abdelmawla (2014) in his research on the effect of zakat and knowledge on poverty reduction in Sudan. His findings showed that zakat had a significant effect on poverty reduction in Sudan in which the increasing percentage of expenditure for the poor from the total zakat funds is highly recommended in reducing inequality in income distribution. Furthermore, the research conducted Nisthar \& Nufile (2017) concerning a comparative analysis of the relation between poverty and the collection of zakat funds and real GDP in Malaysia. Their findings showed that there was a negative relation between poverty reduction and zakat collection and real GDP in which the increase in zakat collection can lead to poverty reduction in Malaysia.

\section{Conclusion and Recomendation}

\subsection{Conclusion}

Zakat, Infaq, Shadaqah (ZIS) has a direct effect on health, economic growth, and HDI. ZIS also indirectly affects economic growth and poverty. This shows that ZIS has a contribution in reducing poverty in Aceh indirectly, namely through Human Development Index (HDI). The Baitul Mal Aceh programs comprising of Education, Health, and Economic Empowerment have the ultimate goal to improve the quality of mustahik, so that the mustahik hopefully can be economically independent and be removed from poverty.

\subsection{Recommendation}

For the central government, in terms of regulations, It is expected that it will be able to make regulations that can maximize the potential of existing zakat funds to be absorbed well like the regulations that direct the public to pay their zakat to the relevant zakat institutions, so that the existing potential can be maximally absorbed. It is also for regulations related to mustahik, such as 
Saputro \& Sidiq | The Role Of Zakat, Infaq and Shadaqah (ZIS) in Reducing Poverty in Aceh Province

regulations regarding integrated data (through Central Bureau of Statistics (BPS) and National Family Planning Coordinating Agency (BKKBN)) so that the distribution of zakat carried out by BAZNAS can be on target.

For the National Amil Zakat Body (BAZNAS) both at the provincial and regional levels, it is recommended to improve its performance in the collection and distribution of ZIS. Therefore, ZIS distribution can be perceived by mustahik or more poor people. In broader scale, it is expected that BAZNAS can begin to reach not only at the provincial and regional levels, but also at sub-district, district, and even neighborhood levels. Thus, the collection of funds can be maximized and its distribution can be perceived by the poor at various levels of the region.

For further researches, this research can be carried out on zakat institutions with good (effective) management of zakat funds and distribution of zakat in other provinces. It is expeced that other findings will be able to provide encouragement for other provinces that are not maximum yet to be able to improve their performance so that the hope is that it can be applied at the national level, and the benefits of the distribution of ZIS funds can be perceived on a wider scale. 
Saputro \& Sidiq | The Role Of Zakat, Infaq and Shadaqah (ZIS) in Reducing Poverty in Aceh Province

\section{References}

Abdelmawla, M. A. (2014). The impacts of zakat and knowledge on poverty alleviation in Sudan: An empirical investigation (1990-2009). Journal of Economic Cooperation and Development, 35(4), 2-46.

Akram, M. M., \& Afzal, M. (2014). Dynamic role of zakat in alleviating poverty: A case study in Pakistan. Munich Personal RePEc Archive.

Athoillah, M. A. (2018). The zakat effect on economic growth, unemployment, and poverty in the Island of Java: Panel data analysis 2011-2012. Ekspansi: Jurnal Ekonomi, Keuangan, Perbankan, Dan Akuntansi, 10(2), 205-230.

Din, T. El. (1986). Allocative and stability function of zakat in an Islamic economy. Journal of Islamic Banking and Finance, 3.

Ghozali, I. (2014). Structural equation modeling, metode alternatif dengan Partial Least Square (PLS) (4th ed.). Semarang: Badan Penerbit Universitas Diponogoro.

Ghozali \& Latan. (2015). Partial Least Square SEM (PLS - SEM). Partial Least Square. https://doi.org/10.1590/s1809-98232013000400007

Hair, J. F., Hult, G. T. M., Ringle, C. M., \& Sarstedt, M. (2013). A Primer on Partial Least Squares Structural Equation Modeling (PLS-SEM). Thousand Oaks. Sage.

Kareem \& Bankole, A. (2016). Zakah, poverty alleviation, and inclusive growth in Nigeria. Journal of Islamic Finance, 5(2), 53-65.

Khasandy, E. A., \& Badrudin, R. (2019). The influence of zakat on economic growth and welfare society in Indonesia. Integrated Journal of Business and Economics, 65-79. https://doi.org/10.33019/ijbe.v3i1.89

Metwally M.M. (1995). Teori dan model ekonomi Islam. Jakarta: PT. Bangkit Daya Insana.

Mohamed, A., Ibrahim, A. A. Bin, Zaidi, N. S. B., \& Kamaruzaman, M. N. Bin. (2019). Does zakat significantly impact on economic growth in Selangor, Malaysia?. International Journal of Academic Research in Business and Social Sciences, 9(6), 786-807. https://doi.org/10.6007/ijarbss/v9-i6/6033

Muhammad, R. (2004). Sejarah Islam di Aceh. Konferensi Tahunan PPs UIN/IAIN/STAIN Se-Indonesia. Banda Aceh.

Mulajawan, Priyonggo, \& Jardine. (2016). Pengelolaan zakat yang efektif: Konsep dan praktik di beberapa negara. Jakarta: Departemen Ekonomi 
Saputro \& Sidiq | The Role Of Zakat, Infaq and Shadaqah (ZIS) in Reducing Poverty in Aceh Province

dan Keuangan Syariah- Bank Indonesia dan P3El Fakultas EkonomiUniversitas Islam Indoensia.

Nisthar, S., \& Nufile, A. A. M. (2017). A comparative analysis of the relationship of nature of poverty with zakat collection and real gross domestic product: An empirical study in the context of Indonesia. Advance Research Journal of Multi-Disciplinary Discoveries, 8(1), 2136.

Nurjanah, F., . K., \& . J. (2019). The impact of economic growth and distribution of zakat funds on poverty (Survey in the Third District of West Java Province Period 2011-2016). KnE Social Sciences. https://doi.org/10.18502/kss.v3i13.4195.

Qardhawi, Y. (2002). Fiqh al-zakah. Beirut: Muassasat Al-Risalah,.

Rédha, B. M., Larbi, G., \& Karima, R. M. (2016). The impact of zakat fund in reducing poverty case of Algeria. Mediterranean Journal of Social Sciences, 7(3), 1-9. https://doi.org/10.5901/mjss.2016.v7n3p256

Sadeq, A. (2006). Development issues in Islam. Malaysia: Internationl Islamic University Malaysia.

Suprayitno, E., Aslam, M., \& Harun, A. (2017). Zakat and SDGs: Impact zakat on human development in the five states of Malaysia. International Journal of Zakat, 2(1), 61-69. https://doi.org/10.37706/ijaz.v2i1.15

Susmodiningrat, G. (2002). Pemberdayaan masyarakat dan jaring pengaman sosial. Jakarta: Gradia Pustaka Utama.

Wibisiono, Y. (2015). Mengelola zakat Indonesia: Diskusi pengelolaan zakat nasional dari rezim Undang-Undang No.38 Tahun 1999 ke rezim Undang-Undang No.23 Tahun 2011. Jakarta: Kharisma Utama. 
Saputro \& Sidiq | The Role Of Zakat, Infaq and Shadaqah (ZIS) in Reducing Poverty in Aceh Province

This page is intentionally left blank 